\title{
MATTHEW ARNOLD ON THE CURRICULUM
}

FEW READERS OF ARNOLD'S LITERARY ESSAYS are able, perhaps, to construct the context of daily work and practical observation from which he spoke or to realize the simple immediacy of his pronouncements. For thirty-five years (1851-1886) Arnold served as Her Majesty's Inspector of Schools, a business that entailed for him a dull and enervating routine; for nineteen years he endured the immense hardship of travelling throughout the winter months by coach and cab on the back-country roads of England and Wales; and--worst of all, perhaps-for the whole period he witnessed the blundering, invidious obstructionism of politicians, always more concerned with religious Voluntaryism than the welfare of children. The religious factions of Arnold's day had prevented the passage of every constructive education act in the British Parliament up to the year 1870 , the year after the publication of his Culture and Anarchy (1869). Arnold's Philistine was no straw man; his sinister presence still pervades the record of the Parliamentary Debates. Arnold saw the Philistine actually in control of the nation's destinythat "wild ass alone by himself," arrogantly and ignorantly out of contact "with the main current of national life"; an "incomplete and mutilated man," with a "natural taste for the bathos," a "want of sensitiveness of intellectual conscience, a disbelief in right reason, a dislike of authority"; a man preoccupied by his "cartloads of rubbish," his morbid concern for "marriage with a deceased wife's sister," his querulous insistence upon the unbounded right to do exactly as he pleased.

With a genius for moderation and the constructive approach, Arnold faced this enormous, this monstrous actuality and declared: "This man does not deserve to be ousted; ousted he will not be, but transformed." The instrument of his transformation was to be "sweetness and light." Arnold's purpose in Culture and Anarchy was "to recommend culture as the great help out of our present difficulties; culture being a pursuit of our total perfection by means of getting to know, on all the matters which most concern us, the best which has been thought and said in the world." All of Arnold's essays that bear a social import, all of his official reports to the Committee of Council on Education ("Education Department"), all of his Commission Reports, of which there were three-all of his utterances on social or political matters attach logically to the central purpose of Culture and Anarchy. England was to be saved, Arnold believed, through the institution of public schools, "honourable because of their public character, and cheap because nationally frequented."

The prophetic grandeur of Arnold's vision can hardly be understood without a glimpse in to the schools that he visited; even with this advantage, perspective is difficult to achieve. The elementary schools of England were organized on the monitorial plan of Joseph Lancaster and Dr. Andrew Bell. With few exceptions they were under the management of two great competing religious societies: The British and Foreign School Society, for the service of Dissenters; and the

FRED G. WALCOTT is a Professor of Education and of English at the University of Michigan in Ann Arbor. 
National School Society, for the service of the Established Church. The report of the Newcastle Commission (1861), upon which Arnold served as Assistant Commissioner, claimed that

\begin{abstract}
"... the first important result which was obtained from the inspection of the state of education in the years 1839-46 was proof of the inadequacy of the monitorial system, and of the inefficiency of the teachers who were then in possession of the schools. The unanimous testimony of the inspectors was that the teachers were bad, and that the monitors, from their extreme youth, were of little use... The consequence of this was that the schools were generally in a deplorable state in every part of England."'
\end{abstract}

Dickens' descriptions of English schools ${ }^{2}$ are by no means caricatures. When Arnold read David Copperfield in 1880, he recognized the accuracy of the depiction of Salem House. "Mr. Creakle's school at Blackheath," he said, "is the type of our ordinary middle class schools, and our middle class is satisfied that so it should be." 3 Elementary schools made little pretense of providing more than the simplest rudiments of reading, writing, and arithmetic, with the addition of simple needle work for the girls. The entire annual cost of such instruction seldom exceeded $£ 1$ per pupil. When in 1862 the so-called "Revised Code" of Mr. Robert Lowe was instituted and "payment by results" became the basic principle for the distribution of the State grants, all effort to maintain a program of more liberal studies was frustrated; the immediate and radical reduction of school income, to be supplied, now, on the basis of results in examinations in reading, writing, and ciphering, drove impoverished teachers to concentrate desperately on the three grant-earning "tool" subjects. So devastating were the dessicating effects of the Revised Code that five years later (1867) the Committee of Council felt obliged to issue a new Minute instituting an additional grant, dependent, among other conditions, upon the inclusion in each school of "one or more specific subjects of secular instruction." In his Report for 1867, Arnold commented on this action: "Meanwhile, the matters of language, geography, and history, by which, in general, instruction first gets hold of a child's mind and becomes stimulating and interesting to him, have in the majority of schools fallen into disuse and neglect. The Minute of last February, which makes them subjects of a grant-bringing examination has, by recalling attention to them, made manifest into what decay they had sunk."'

Such was the milieu from which Arnold beheld the instrument of British social regeneration; even from such a dismal prospect, he must recommend "culture as the great help out of our present difficulties; culture being a pursuit of our total perfection by means of getting to know, on all the matters which most concern us, the best which has been thought and said in the world; and through this knowledge, turning a stream of fresh and free thought upon our stock notions and habits, which we now follow staunchly but mechanically, vainly imagining that there is a virtue in following them staunchly which makes up for the mischief

${ }^{1}$ Report of the Commissioners Appointed to Inquire into the State of Popular Education in England (London: Eyre and Spottiswoode, 1861), Vol. I, p. 98.

'See especially his discussion of the Yorkshire schools in the preface to Nicholas Nickleby.

${ }^{3}$ George W. E. Russell, The Letters of Matthew Arnold 1848-1888 (London: Macmilian \& Co., 1895), Vol. II, p. 184.

${ }^{4}$ Reports on Elementary Schools, 1852-1882 (London: Macmillan and Co., 1889), p. 123. 
of following them mechanically. ${ }^{5}$ Here is the remarkable faith of the Humanist, whose basic assumption is always the perfectibility of man. And here is the Humanistic doctrine of human expansion through liberal studies, a doctrine that underlay all that Arnold ever said, either in his belles lettres or in his official reports. The student of Arnold, however, will form a very inadequate concept of his universe of thought and experience from a preoccupation only with the literary side; the scope and consistency of his thinking are to be discovered in a study of his professional advices to the Committee of Council and to British officialdom in general.

\section{The Case for the Humanities}

Having comprehended Arnold's exalted view of the humanities as a power in human life, one may be surprised by the moderation of his recommendations concerning their place in the curriculum. The study of literature as it is known today-the reading and discussion of the classics; the concerted quest for the literary experience; imaginative identification with literary persons, times, and places-such edifying activities were practically unknown in the British schools that Arnold inspected. Even on the secondary level, the study of the ancient languages, which underlay the discipline of the great Public Schools and of the grammar schools, by no means supplied this humanizing function. The study of classical antiquities was only a dull and stultifying preoccupation with formal syntax and prosody, a dissection of fragments whose spiritual meanings were but imperfectly understood. ${ }^{6}$ Thomas Henry Huxley had complained that at its best it meant only "turning Latin and Greek into English, for the mere sake of being able to do it," and with the end result that after a dozen years of this drudgery, "the sufferer shall be incompetent to interpret a passage in an author he has not already got up; that he shall loathe the sight of a Greek or Latin book; and that he shall never open, or think of, a classical writer again, until, wonderful to relate, he insists upon submitting his sons to the same process."

If these were the complaints of an invidious educational intruder-and I think that they were not-Arnold, at least, was fully aware of the abuses that had inspired them. In his Report to the Schools Inquiry Commission of 1868, he commented at length to the same effect, but in a much more moderate vein. Here he complained that "the prolonged philological discipline, which in our present schools guards the access to Alterthumswissenschaft," precludes any entrance into the larger, more edifying field; and nine students out of ten, "especially in England, where so much time is given to Greek and Latin com-

${ }^{5}$ Culture and Anarchy (New York: Macmillan \& Co., 1883), p. xi.

${ }^{6}$ Arnold's associate on the Newcastle Commission, the Rev. Mr. Pattison, thus describes his first freshman class at Oriel College, Oxford, under G. A. Denison, "who had a reputation as a scholar." When the class came to the first lyrics of the Alcestis, the tutor asked: "'What metre is this?' It went the round, no one had any idea; it came to me, and I answered, 'Anapaestic dimeter.' So much information was not far to fetch, for Monk had a note on the metre of the passage, and most of the class had Monk, but they had not read the Latin note. Denison gave me a look as much as to say, "Who the devil are you?' He had evidently not been accustomed in his class to meet with such profound learning. I do not remember in the whole course of the term that Denison made a single remark on the two plays, Alcestis and Hippolytus, that did not come from Monk's notes" (Memoirs, London: The Macmillan Co., 1885, pp. 65-66).

7"A Liberal Education and Where to Find It," Collected Essays (New York and London: D. Appleton and Co., 1917), Vol. III, pp. 100-101. 
position, never get through the philological vestibule at all, never arrive at Alterthumswissenschaft, which is a knowledge of the spirit and power of Greek and Roman antiquity learned from its original works." 8

The state of instruction in the elementary schools was even more depressing to a professional observer. In Arnold's first Report to the Committee of Council, he commented upon the shortcomings of the pupil-teachers, who, despite a surprising knowledge of grammatical, geographical, historical, and mathematical facts, could not "paraphrase a plain passage of prose or poetry without totally misapprehending it, or write half a page of composition on any subject without falling into gross blunders of taste and expression."' In the Report for the year 1867 , he deplored the gross inadequacy of the textbooks in common use, books compiled by charlatans and mercenaries, with no cultural aptitudes or professional skill. The pupil's reading book, he said, "is often the only book of secular literature in his possession; it is important to do what we can to ensure its being a good one." He deplored especially the bad poetry contained in these books and quoted an example entitled "My Native Land," from "the Fifth Standard book of a series much in vogue":

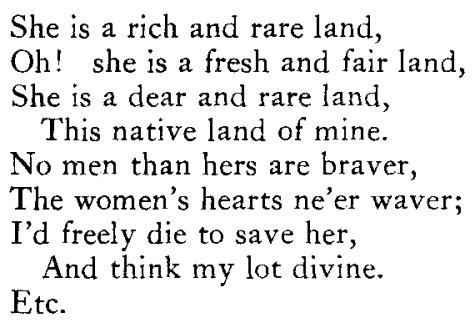

"When one thinks how noble and admirable a thing genuine popular poetry is," Arnold protested, "it is provoking to think that such rubbish as this should be palmed off on a poor child for it with any apparent sanction from the Education Department and its grants."10

Always Arnold sought for opportunities to impress upon his superiors the need for fostering the humanizing influence of the school. To get literature into the minds of the pupils was his constant aim. For this reason he had been particularly gratified by the introduction of "recitation" into the list of "special subjects." "Recitation" meant simply the memorizing and repeating of literary selections. As a cultural activity, it appealed strongly to Arnold. The great majority of schools now included this activity as an "extra subject"; and while he was extremely gratified at the recognition of this exercise, he was much concerned over the bad selection of passages to be learned. Moreover, the learner appeared in all too many cases to misapprehend the sense of what he recited.

"More and more [Arnold averred] the recitation should be turned into a literaturelesson. None but classical poetry should be taken; we are far too much afraid of restriction and uniformity. The young ought in school to be as much as possible restricted to good models; the merit of the old classical education was that it kept the pupil in continual contact with a few first-rate models."

${ }^{8}$ Schools and Universities on the Continent (London: Macmillan \& Co., 1868), p. 262.

${ }^{9}$ Reports on Elementary Schools, pp. 18-20.

${ }^{10}$ Ibid., pp. 129-130.

${ }^{11}$ Ibid., p. 183. 
What was needed, Arnold suggested, was an inclusion in the syllabus of the Education Department of a short work of classical English poetry, to be presented in the training colleges to the candidates for admission, and subsequently to be adopted for the recitation and literature-lesson in the elementary schools. Thus carefully studied by the teacher-candidates, Arnold believed, "it would have a good chance of being appropriated and assimilated by both pupils and pupilteachers, and only thus can such a work produce its due effect. Its due effect, when produced, is invaluable, and is precisely that of which our elementary schools stand most in need."12

Arnold would have the whole upper part of the school memorizing from one hundred to three hundred lines of good poetry each year. But with something of an adaptive principle, he would not be so rigid as to exclude all poetry but the very best for the memory exercise. The poetry of Scott or of Mrs. Hemans, for example, might be admitted. Such poetry "is no doubt of texture different from that of the best poetry, yet it has excellent qualities, and qualities to which our school-children are very sensible; we may be glad to have them learning it." Still, in an effort to set a high standard, he would prefer Gray's Elegy and extracts from Shakespeare to the poetry of Scott and Hemans. ${ }^{13}$

\section{Selections from the Bible as a Formative Factor}

It was Arnold's concern for the formative influence of the school that led him so often to recommend the inclusion of Scriptural passages and the hymns of the Church. He was wont to complain of the total ignorance of Biblical knowledge among the children in British schools; and in order to remedy this defect, he published, in 1872, A Bible Reading for $S$ chools, consisting of Chapters XL-LXVI of Isaiah. He protested the folly of expecting the Sunday schools to supply this important educational service, and he insisted that within the elementary schools, instruction in the knowledge of the Bible should be brought under official inspection. He exhorted the managers of the British and Foreign Schools to set an example for other managers in this respect:

"Let them make the main outlines of Bible history, and the getting by heart a selection of the finest Psalms, the most interesting passages from the historical and prophetical books of the Old Testament, and the chief parables, discourses, and exhortations of the New, a part of the regular school work, to be submitted to inspection and to be seen in its strength or weakness like any other."14

"There was no Greek school," said Arnold, "in which Homer was not read; cannot our popular schools, with their narrow range and their jejune alimentation in secular literature, do as much for the Bible as the Greek schools did for Homer?"'15 And in his last formal report on the schools of the Continent (1886), he deliberately emphasized the cultural power of the religious instruction which he had witnessed in Germany:

12Ibid., pp. 183-184.

${ }^{13}$ Ibid., p. 211.

${ }^{14}$ Ibid., pp. 151-152.

${ }^{15}$ Ibid., p. 152. 


\begin{abstract}
"The chief effect of the religious teaching, however, certainly lies in the Bible passages, and still more in the evangelical hymns, which are so abundantly learnt by heart and repeated by the children. No one could watch the faces of the children, of the girls particularly, without feeling that something of their nature responded to what they were repeating, and was moved by it. It is said that two-thirds of the working classes in the best educated countries of Protestant Germany are detached from the received religion, and the inference is drawn that the religious teaching in the schools must be a vain formality. But may it not happen that chords are awakened by the Bible and hymns in German schools which remain a possession even though the course of later life may carry the German adult far away from Lutheran dogma?"'15
\end{abstract}

In the Preface to the reprinted edition of his Special Report (1888), Arnold directed the attention of his readers to three important points, the last of which was, "that religious instruction ... is a formative influence, and more indispensable in the popular school than in any other."17

In his eagerness to humanize the school, to supply some particle of the cultural leaven, Arnold often resorted, no doubt, to questionable, perhaps to desperate, suggestions. Perspective is indispensable if one would weigh his judgments equitably. To a modern educator, once he has comprehended the cultural degradation so common in the schools of that period, Arnold sometimes seems to be aiming hopelessly high in the constructive advices that he offers. There is no evidence that his $A$ Bible Reading for Schools was ever used in any British school. And yet, waiving the vexing problem of disparity between the actual conditions and the ideal remedy that Arnold prescribed, one cannot help admiring his cultural aims and commending the motive of his efforts.

\title{
Grammar as a Cultural Discipline
}

There is little that Arnold ever said in his official reports or in the literary essays that flowered within his educational milieu but has this distinctive, this persistent idealism. Even his comments on grammar and on the ancient and modern foreign languages take their inspiration from this source. He was harassed and afflicted by the linguistic ineptitude, the mental squalor of the young pupils whom he examined. Surveying sadly, but never despondently, this valley of dry bones, he placed the onus for quickening it squarely upon the State. It is an "animation of mind," the "multiplying of ideas," that is needed--" the promptness to connect, in the thoughts, one thing with another, and to illustrate one thing by another"; it is "just what letters, as they are called, are supposed to communicate." And so in examining the candidates for admission to the training schools, it is to the grammar papers that he looks with special interest:

"The grammar paper is that paper in their examination which most directly deals with letters, properly so called, and which best shows us, therefore, the amount of the candidate's hold upon letters, and the chance of his communicating the power of letters to others.

"The candidate has to paraphrase a passage of English poetry, and no exercise

${ }^{16}$ Special Report on Certain Points Connected with Elementary Education in Germany, Switzerland, and France (Reprinted by the Education Reform League, I.ondon: Toynbee Hall, Whitechapel, 1888), p. 17.

${ }^{17}$ Ibid., p. 2. 
can better show his range of ideas and quickness of apprehension. He has to parse and analyse sentences, and no exercise can better show his clearness of understanding and his power of reasoning. He has to answer a few questions about our own language or literature. Altogether, the paper is one which tests his information, judgment, and taste more thoroughly than any other of his papers tests them."18

But even in this direction he finds little encouragement. The candidates have been chosen as the most successful products of the school; they have remained under instruction until the age of eighteen or nineteen, serving throughout their last five or six years as pupil-teachers and assistants, they are destined to return to the schools after two or three years of higher learning as principals and masters. The "grammar papers," however, are most disappointing. There has been no mental quickening; indeed, it seems "as if the picked scholars of our elementary schools were further off from it now than they were twelve years ago." 19 As a paraphrase of a passage from Campbell's Gertrude of Wyoming, which begins:-

"Far differently the mute Oneyda took

His calument of peace and cup of joy;

As monumental bronze unchanged

his look."-

he receives: "His demeanour was as unchangeable as ornamental iron-work," which, Arnold says, is a good specimen. ${ }^{20}$

In distinguishing between adverbs and conjunctions, adverbs and prepositions, adverbs and adjectives, one student answered: "If a word is used to connect sentences, to govern nouns and pronouns, to point out any quality or circumstance respecting the noun, it is clearly not an adverb." And here he might have rested, but he did not; he added this damaging qualification: ". . . there is, however, a rule which says that if a word is not wanted in a sentence for any of the above ways, it shall be thrown into the common sink, which is adverbs." And that, said Arnold, "has really a kind of merit."

Apparently Arnold's disillusionment attached to the scholars alone and not to the subject itself; for two years later (1876) he defended grammar as one of the most important of the extra subjects:

"Grammar and geography should be the first of the class subjects chosen, ${ }^{22}$ and in the schools under my inspection they generally are so. I cannot understand the doubts of some of my colleagues as to the use of teaching grammar. The programme of a French elementary school is notoriously scanty, but it always includes the elements of French grammar. Grammar is an exercise of the

${ }^{18}$ Reports on Elementary Schools, pp. 175-176.

${ }^{19}$ Written in 1874, twelve years after the date of the Revised Code.

${ }^{20}$ Reports on Elementary Schools, p. 177.

${ }^{21}$ Ibid., pp. 179-180.

22The Code of 1871 set up the following list of "specific subjects": geography, history, grammar, algebra, geometry, natural philosophy, physical geography, the natural sciences, political economy, languages, "or any definite subject of instruction... sufficiently distinct from the ordinary Reading Book Lessons to justify its description as a "Specific Subject of Instruction"” (Report of Committee of Council on Education, 1870-71, London: Eyre and Spottiswoode, 1871, p. cxxiv). 
children's wits; all the rest of their work is in general but an exercise of their memory. To learn the definitions and rules of grammar is, indeed, but an exercise of memory. But, after learning the definition of a noun, to recognize nouns when one meets with them, and to refer them to their definition, that is an exercise of intelligence. I observe that it animates the children, even amuses them. Indeed, all that relates to language, that familiar but wonderful phenomenon, is naturally interesting if it is not spoiled by being treated pedantically." ${ }^{23}$

Arnold's theories of educational discipline rested, as one would certainly expect, upon the basic assumptions of a facultative psychology. But that he should have completely overlooked the principle of successful learning, as a test of expediency in educational practice is a little surprising. That those highlyselected students should have failed, after twice the normal interval of tuition and with all the special advantage of cumulative repetition over the same rudimentary lessons, not only as common pupil-learners but as chosen assistantteachers- that they should have failed thus, despite an admitted special aptitude and despite an extraordinary mental maturity, seems not to have impressed him at all, neither as to the inutility of the effort nor as to the questionable worth-for these students--of the materials offered. With this failure before his eyes, he must still acclaim the humanizing virtues of the subject, not only for those superior students who have failed, but for the rank and file of younger children whose inexperience within the realm of abstract ideas must have approached perilously close to the absolute.

His misjudgment, however, deserves some extenuation. Within a field of endeavor so new and uncharted as elementary education, he must of course proceed empirically. To rationalize was not one of Arnold's conspicuous faults, but, in his speculative advances upon the new frontier, he must reckon with tradition. And tradition was rigoristic. Reflecting dispassionately upon the obduracy of these familiar bonds, one is rather impressed with Arnold's liberality. The important point of the matter is not his overlooking the difficulty of the exercise nor the "ineducability" of the pupils, but rather the extremity to which he was driven in his attempt to secure for the children of England some germinal grain of the cultural leaven. One knows that he was dealing out desperate remedies, but also that his own horizons were wider than this. An excellent example of his inner, unfettered judgment occurs in a letter, written ten years earlier (January, 1866), to his sister " $\mathrm{K}$ " (Mrs. William E. Forster):

"If it is perception you want to cultivate in Florence ${ }^{24}$ you had much better take some science (botany is perhaps the best for a girl, and I know Tyndall thinks it the best of all for educational purposes) and, choosing a good handbook, go regularly through it with her. Handbooks have long been the great want for teaching the natural sciences, but this want is at last beginning to be supplied, and for botany a text-book based on Henslow's Lectures, which were excellent, has recently been published by Macmillan. I cannot see that there is much got out of learning the Latin grammar except the mainly normal discipline of learning something much more exactly than one is made to learn anything else; and the

${ }^{23}$ Reports on Elementary Schools, pp. 189-190.

${ }^{24}$ One of the four children of William Delafield Arnold, a brother of Matthew and Mrs. Forster, who died at Gibraltar on April 9, 1859, while returning home from India (see Letters, Vol. I, pp. 79-80). William's wife having died a year earlier, the four orphans were adopted by the Forsters ( $T$. Wemyss Reid, Life of the Rt. Hon.W. E. Forster, London: Chapman and Hall, Ltd., 1888, Vol. I, pp. 316-318). 
verification of the laws of grammar, in the examples furnished by one's reading, is certainly a far less fruitful stimulus of one's powers of observation and comparison than the verification of the laws of a science like botany in the examples furnished by the world of nature before one's eyes. The sciences have been abominably taught, and by untrained people, but the moment properly trained people begin to teach them properly they fill such a want in education as that which you feel in Florence's better than either grammar or mathematics, which have been hitherto so far better studied and known. Grammar and pure mathematics will fill a much less important part in the education of the young than formerly, though the knowledge of the ancient world will continue to form a most important part in the education of mankind generally. But the way grammar is studied at present is an obstacle to this knowledge rather than a help to it, and I should be glad to see it limited to learning thoroughly the exampleforms of words, and very little more - for beginners, I mean. Those who have a taste for philosophical studies may push them further, and with far more intelligible aids than our elementary grammars afterwards. So I should inflict on Florence neither Latin nor English grammar as an elaborate discipline; make her learn her French verbs very thoroughly, and do her French exercises very correctly; but do not go to grammar to cultivate in her the power you miss, but rather to science." "25

Here, as he ministers unto his own, with his judgment unencumbered by the desperate conditions of the popular schools, we apprehend his true opinions; and they are practical and urbane.

\section{Science as a Humanizing Agent}

Arnold's solicitude for literary studies should arouse little surprise, harbored as it was by a great literary figure. His concern for science, however-certainly as vigorous as that for any other subject-is a most remarkable evidence of his urbanity. As an inclusion in the curriculum of English schools, science came very late, and its entrance was by the back door. With the rise of "institutes" for mechanics in the mid-Nineteenth Century, science won a place, not as a liberal study but, on the contrary, as a gross, plebeian matter quite appropriate for workmen and mechanics, who could make no claim to culture. The first State grants for science were made in 1859, the year of The Origin of Species; these grants were made only to special schools (South Kensington Schools), administered separately by the Science and Art Department. The "Schools of Science" were maintained in complete separation from the common schools until 1899. It was these schools that Huxley was called in to reorganize in 1872, and it was these for which he wrote the curriculum.

Now Arnold deplored the narrow, utilitarian purpose of all special schools. Even the university of Mr. Ezra Cornell, ${ }^{26}$ he said, is " a really noble monument of his munificence, yet seems to rest on a misconception of what culture truly is, and to be calculated to produce miners, or engineers, or architects, not sweetness and light."27 It was to obviate a vicious provincialism-to circumvent the xenophobic ambitions of "ordinary men, with their natural taste for the bathos

${ }^{25}$ Letters, Vol. I, pp. 313-314.

${ }^{26}$ Founder of Cornell University (1868) at Ithaca, New York.

${ }^{27}$ Culture and Anarchy, p. xxvii. 
still strong," that he recommended the founding of Crown patronage schools, of the type that he had seen in Germany:

"And it will be allowed, probably, that right reason would suggest that, to have a sheer school of Licensed Victuallers' children, or a sheer school of Commercial 'Travellers' children, and to bring them all up, not only at home but at school too, in a kind of odour of licensed victualism or of bagmanism, is not a wise training to give to these children." 28

But deploring all specialization of a provincial character, Arnold always recognized, nevertheless, the cultural power of science as a liberalizing study. He saw the circle of human knowledge as entered from two great roads:

"To know himself, a man must know the capabilities and performances of the human spirit; and the value of the humanities, of Altertbumswissenschaft, the science of antiquity, is that it affords for this purpose an unsurpassed source of light and stimulus...

“... But it is also a vital and formative knowledge to know the world, the laws which govern nature, and man as a part of nature. This the realists have perceived, and the truth of this perception, too, is inexpugnable. Every man is born with aptitudes which give him access to vital and formative knowledge by one of these roads; either by the road of studying man and his works, or by the road of studying nature and her works." 29

It was only as he was forced to choose between the claims of one faction or the other, as to the comparable values of the two, that he would express a preference:

"But it seems to me that so long as the realists persist in cutting in two the circle of knowledge, so long do they leave for practical purposes the better portion to their rivals, and in the government of human affairs their rivals will beat them. And for this reason. The study of letters is the study of the operation of human force, of human freedom and activity; the study of nature is the study of the operation of non-human forces, of human limitations and passivity. The contemplation of human force and activity tends naturally to heighten our own force and activity; the contemplation of human limits and passivity tends rather to check it." ${ }^{30}$

Most readers will recognize the purely polemical character of Arnold's argument, but the tenor of his faith is unmistakable. His humanism was broad and all-inclusive. The apocryphal rumor of his quarrel with Huxley has continued to delude students to the present day; for he had no quarrel with Huxley. Their correspondence over the respective merits of science and letters was a voluntary demonstration, on the part of Arnold at least, of their essential agreement on a great cultural discipline. Throughout the official reports, moreover, there are constant examples of Arnold's concern for an adequate offering of science in the schools. This was especially true of the secondary schools, the much-hoped-for instrument of Philistine regeneration-that great middle class, cheated and deprived of its social prerogative through the indifference of the superior classes and its own ignorant complicity, brought up on the second plane, insufferably and arrogantly proud of its own inanities. "If only, in compensation, it had

${ }^{28}$ Ibid., p. 97.

${ }^{29}$ Schools and Universities on the Continent, p. 258.

${ }^{20}$ Ibid., p. 260. 
science, systematic knowledge!"'31 Arnold was one of the strongest advocates that the partisans of practical science ever had.

\section{Examinations and the Cult of Educational Rigorism}

Rigorism, in its stern and ascetic sense, was foreign to Arnold's nature. In his philosophical speculations, while surveying the awkward gap between theory and accomplishment, he would often recommend a rugged discipline; never because he trusted in the virtue of a stern and rocky road, but because he sometimes failed to estimate properly the interval between the powers of maturity and those of childhood. Temperamentally he was a kind and generous teacher. He had a natural antipathy for examinations and thought that English boys were crammed and examined to surfeiture. Speaking of the French lycees, he said that they were "guiltless of one preposterous violation of the laws of life and health committed by our own schools," the competitive examination for places on their foundations.

It was in this respect that Arnold had been most favorably impressed with the Prussian system. There he saw examinations drawn up "to tempt candidates to no special preparation and effort, but to be such as "a scholar of fair ability and proper diligence may at the end of his school course come to with a quiet mind and without a painful preparatory effort and tending to relaxation and torpor as soon as the effort is over." 32 In Prussia it was the total cultivation of the candidate that was tested, not the information that he had been able to cram. "Accordingly, the composition and the passages for translation are great matters in German examinations, not those papers of questions by which the examiner is so led to show his want of sense, and the examinee his stores of cram." ${ }^{33}$

Likewise, in the German Universities, Arnold thought, it was the inculcation of the love of study and of science for their own sakes that prevailed. In Austria, "a country which believes in the things of the mind as little as we do," the examinations were applied with a "mechanical faith" much like that of the English. And for this a country pays with a lowered intellectual life. "All I say is," concluded Arnold, "that a love for the things of the mind is what we want, and that examinations will never give it." 34

\section{Literature and the Humanization of Man in Society}

It was in Germany also that Arnold found in greatest prominence the genuine cultural idealism that he himself exemplified-a mental attitude, a spiritual predisposition toward the things of the mind, that was reflected in both content and the method of instruction. In his last report on the elementary schools of Germany (1886), he commented at length upon this most essential aspect:

"But the higher one rises in a German school the more is the superiority of the instruction over ours visible. Again and again I find written in my notes, The cbildren buman. They had been brought under teaching of a quality to touch and interest them, and were being formed by it. The fault of the teaching in

${ }^{31}$ Ibid., p. 277.

32Tbid., p. 182.

${ }^{3}$ Ibid.

${ }^{34}$ Ibid., p. 230. 
our popular schools at home is, as I have often said, that it is so little formative; it gives the children the power to read the newspaper, to write a letter, to cast accounts, and gives them a certain number of pieces of knowledge, but it does little to touch their nature for good and to mould them.... The excellent maxim of that true friend of education, the German schoolmaster, John Comenius, "The true aim is to train generally all who are born men to all which is human," does in some considerable degree govern the proceedings of popular schools in German countries, and now in France also, but in England hardly at all."35

Here we read the considered judgment of an aging Arnold, uttered only two years before his death, and comprehending the accumulated experience of thirty-five years of intimate association with the schools he criticized. It was the humanistic, the belles-lettristic function that he sought to establish-the study, the discussion, the critical analysis among congenial minds of great pieces of literature.

It was this aim that underlay Arnold's editing, in 1878, of Doctor Johnson's "six chief Lives," Milton, Dryden, Swift, Addison, Pope, and Gray. Arnold complained of the want of organization, the lack of any "well-grounded consent" as to what and how much should be taught. He pleaded for "a severe limitation in the number of matters taught, a severe uniformity in the line of the study followed. Wide ranging, and the multiplication of matters to be investigated, belong to private study,- - to the development of special aptitudes in the individual learner, and to the demands which they raise in him." ${ }^{36}$ He suggested certain points de repere or important centers of knowledge; and for the study of English literature, the six chief Lives of Johnson would serve admirably such a purpose. "To how many of us," he protests, "are Pope and Addison and Dryden and Swift, and even Milton himself, mere names, about whose date and history and supposed characteristics of style we may have learnt by rote something from a handbook, but of the real men and of the power of their works we know nothing!'37 Arnold urged that the literature be studied, the literature of each, in connection with the study of his life.

With the same aim, and with the same eager interest, Arnold examined Stopford Brooke's A Primer of English Literature. In his review of this book, ${ }^{38}$ Arnold again urged the importance of the quality of the literature taught. "Once secure what is excellent to be taught, and you can hardly teach it with too much insistence, punctuality, universality." In fact, Arnold deprecated multiformity and urged uniformity-uniformity in good. "Nothing is taught well except what is known familiarly and taught often. The Greeks used to say... Give us a fine thing two and three times over! And they were right." ${ }^{9}$

In 1879 Arnold collected into a new volume a number of his former essays, including one, his "Democracy," published eighteen years earlier as an

${ }^{35}$ Special Report on Certain Points Connected with Elementary Education in Germany, Switzerland, and France, pp. 16-17.

${ }^{36}$ The Six Chief Lives from Johnson's "Lives of the Poets" (London: The Macmillan and Co., 1881), p. $\mathrm{x}$

st Ibid., p. xv.

38" A Guide to English Literature," Mixed Essays, Irish Essays, and Others (New York: Macmillan $\&$ Co., 1901), pp. 135-153.

${ }^{39}$ Ibid., p. 136.

${ }^{40}$ The Popular Education of France, with Notices of That of Holland and Switzerland (London: Longman, Green, Longman and Roberts, 1861). 
concerning his experiences and opinions. Conversely, when the teacher is asked a question by the student, his reply should proceed from the depths of his own personal experience. ${ }^{27}$

The use of concepts without a clear knowledge of their significance leads to a confusion and empty talk that disrupts society. The trainer of the teachers of the people must, therefore, inculcate in them above all a sense of responsibility with regard to concepts and speech. In order to do this he must use class discussion for the purpose of testing the reliability of concepts. The curriculum of these classes must arise from the social, political, and cultural reality of life at this historical juncture, writes Buber, and the inferences to be drawn from this curriculum must come about of their own accord in the minds of the students. In order to be able to teach in an immigration camp, the student has to learn to live with people in all situations of their lives, and for this reason the teachers at the institute are prepared to deal with the personal lives of the students. This concern with the students' personal lives does not mean that the students do not learn the classics, Jewish and otherwise, but they do so in order that they may become whole persons able to influence others and not for the knowledge itself. "Adult education is concerned with character," says Buber, "and character," he adds, "is not above situation, but is attached to the cruel, hard demand of this hour." 28

${ }^{27}$ Martin Buber, "A New Venture in Adult Education," The Hebrew University in Jerusalem, Semi-Jubilee Volume (Jerusalem: The Hebrew University, April, 1950), p. $117 \mathrm{f}$.

${ }^{28}$ Ibid., p. 118f. "Adult Education in Israel."

\section{MATTHEW ARNOLD ON CURRICULUM (Continued from page 85)}

introduction to his first foreign report. ${ }^{40}$ Seeking to explain the unifying tendency of these Mixed Essays, he presented, in his Preface, a theory of literature as a civilizing power - literature being of itself only a part of civilization, not the whole. "What then," asked Arnold, "is civilization, which some people seem to conceive of as if it meant railroads and the penny post, and little more, but which is really so complex and vast a matter that a great spiritual power, like literature, is a part of it, and a part only? Civilization is the humanization of man in society. Man is civilized when the whole body of society comes to live with a life worthy to be called human, and corresponding to man's true aspirations and powers." And among the means by which this happy state was to be attained, the familiar power of expansion stood at the pinnacle of importance. That basic principle being given, he proceeded to enumerate the other powers by which civilization was to be achieved: "They are the power of conduct, the power of intellect and knowledge, the power of beauty, the power of social life and manners. Expansion, conduct, science, beauty, manners,here are the conditions of civilization, the claimants which man must satisfy before he can be humanised." 41 If one were to seek a single unifying principle by which to comprehend all that Arnold ever said about the curriculum, he could do no better than to seize upon this: Expansion, conduct, science, beauty, manners these are the province, the sole, the universal province of the schools.

${ }^{41}$ Preface to Mixed Essays (New York: The Macmillan Co., 1901), pp. vii-x. 